\title{
MEMUTUS MATA RANTAI PRAKTIK PROSTITUSI DI INDONESIA MELALUI KRIMINALISASI PENGGUNA J ASA PROSTITUSI
}

\author{
Apriliani Kusumawati ${ }^{*}$, Nur Rochaeti2 \\ IFakultas Hukum, Universitas Sebelas Maret \\ 2Fakultas Hukum, Universitas Diponegoro \\ apriliani93@gmail.com
}

\begin{abstract}
Prostitution in Indonesia is always seen from a patriarchal perspective, where Prostituted Women are always the object and accusation of the source of the problem. They are punished by the State as perpetrators of crime while consumer of prostitution are considered reasonable. The criminalization of prostitution consumers is urgent to break the chain of practice of prostitution. The author finds that Indonesia has various laws and regulations which contain a prohibition on prostitution, including in the Criminal Law Code, Law Number 21 of 2007 on Elimination of Human Trafficking Crimes, Law Number 44 of 2008 on Pornography, Law Number 35 of 2014 on Child Protection, and Law Number 19 of 2016 on Electronic Information and Transactions. But, the regulation is not yet comprehensive to ensnare the parties involved in prostitution, especially the prostitution consumers. Prohibition of prostitution can be carried out through special legislation on prostitution or by ratify the legal draft on the Elimination of Sexual Abuse.
\end{abstract}

Keyword: Criminalization; Prostitution; Prostitution Consumers.

\begin{abstract}
ABSTRAK
Selama ini prostitusi di Indonesia dipandang dengan cara pandang patriarki, dimana Perempuan yang Dilacurkan (Pedila) selalu menjadi objek dan tudingan sumber permasalahan. Pedila dihukum oleh Negara sebagai pelaku tindak pidana, sedangkan pengguna jasa prostitusi dianggap wajar, padahal praktik prostitusi akan terus ada selama masih banyak "permintaan/demand" dari pengguna jasa prostitusi. Karenanya, gagasan kriminalisasi bagi pengguna jasa prostitusi mendesak untuk dilakukan dalam upaya memutus mata rantai praktik prostitusi. Penulis menemukan bahwa Indonesia terdapat berbagai peraturan perundang-undangan yang memuat larangan prostitusi, antara lain terdapat dalam Kitab Undang-Undang Hukum Pidana, Undang-Undang Nomor 21 Tahun 2007 tentang Tindak Pidana Perdagangan Orang, Undang-Undang Nomor 44 Tahun 2008 tentang Pornografi, Undang-Undang Nomor 35 Tahun 2014 tentang Perubahan Atas Undang-Undang Nomor 23 Tahun 2002 tentang Perlindungan Anak, dan Undang-Undang Nomor 19 Tahun 2016 tentang Perubahan Atas Undang-Undang Nomor 11 Tahun 2008 tentang Informasi dan Transaksi Elektronik. Namun aturan tersebut belum komprehensif untuk menjerat para pihak yang terlibat dalam prostitusi, khususnya pengguna jasa prostitusi. Penindakan dapat dilakukan melalui penyusunan peraturan perundang-undangan khusus terkait prostitusi atau dengan segera mengesahkan Rancangan Undang-Undang Penghapusan Kekerasan Seksual.
\end{abstract}

Kata Kunci: Kriminalisasi; Prostitusi; Pengguna Prostitusi.

\footnotetext{
* Corresponding Author
} 


\section{A. PENDAHULUAN}

Prostitusi senantiasa ada dalam setiap periode sejarah. la bukanlah fenomena baru, begitupun di Indonesia. Praktik prostitusi dapat ditemui mulai dari keberadaan para selir untuk para laki-laki bangsawan, para Nyai untuk para pejabat Vereenigde Oostindische Compagnie (VOC) milik pemerintah kolonial Belanda, hingga perbudakan seks yang dilakukan tentara Jepang terhadap para perempuan yang merupakan warga lokal di negara-negara jajahan Jepang. Sejarah memperlihatkan bahwa prostitusi terjadi karena masalah ekonomi, politik, dan pola pikir patriarki yang menjadikan perempuan sebagai obyek dan pelayan seksual.

Setelah merdeka, masalah prostitusi di Indonesia menjadi semakin kompleks. Antara tahun 1960-an hingga 1970-an, urbanisasi marak terjadi. Prostitusi kemudian menjadi masalah tersendiri dalam problem perkotaan. Banyak bermunculan tempat-tempat prostitusi besar yang bertahan hingga saat ini.

Dalam prakteknya, aktivitas prostitusi sangat beragam, ada yang terorganisir dan ada yang individual. Bentuk dari prostitusi yang terorganisir adalah munculnya lokalisasi, contohnya adalah klub malam, rumah berdir, dan panti pijat. Sedangkan yang tidak terorganisir dapat ditemukan pada perempuan yang menjajakan diri di pinggir jalan dari pasaran kelas menengah hingga kelas bawah (Khumaerah, 2017).

Secara etimologis kata prostitusi berasal dari kata prostitutio yang memiliki arti menawarkan, menempatkan, dihadapkan (Tampi, 2010). Kamus
Besar Bahasa Indonesia (KBBI) memberikan definisi bahwa prostitusi adalah pertukaran hubungan seksual dengan uang atau hadiah sebagai suatu transaksi perdagangan; pelacuran. Definisi serupa juga termuat dalam Black's Law Dictionary yang menyatakan bahwa prostitution is the act of practice of engaging in sexual activity for money or its equivalent, commercialized sex.

Menyimak penelitian Perkumpulan Keluarga Berencana Indonesia (PKBI) pada April 2007, terdapat 3 (tiga) alasan yang melatarbelakangi perempuan bekerja di dunia prostitusi, antara lain (1) kemiskinan; (2) pendidikan rendah; dan (3) merupakan korban kekerasan yang tidak punya akses terhadap layanan pemulihan (Katjasungkana, 2014).

Assessment yang dilakukan LBH APIK Semarang pada 2010 menunjukkan pola yang sama. Sebagian besar Pedila di 2 (dua) lokalisasi di Semarang menyatakan bahwa sebelum jatuh ke dunia prostitusi, mereka mendapat kekerasan baik berupa Kekerasan dalam Rumah Tangga (KDRT) maupun kekerasan seksual dari pacar dan pelaku lain. Bahkan di antaranya diperkosa oleh lebih dari 1 (satu) orang pelaku. Mereka mengaku tidak ada yang menolong baik dari masyarakat maupun aparat negara (Katjasungkana, 2016).

Prostitusi telah mereduksi individu dari wujud manusia menjadi komoditas yang diperjualbelikan (Nazemi, 2011). United Nations Global Initiative to Fight Human Trafficking menjabarkan penyebab umum terjadinya perdagangan manusia, yang di dalamnya termasuk juga dalam hal prostitusi, antara 
lain: (1) kekerasan berbasis gender; (2) praktek ketenagakerjaan yang diskriminatif; (3) struktur sosial yang patriarkal; (4) memudarnya jaringan ikatan keluarga; (4) pernikahan dini; (5) tingginya laju perceraian; (6) terbatasnya pendidikan; terbatasnya kesempatan ekonomi; (8) pemerintah yang korup dan gagal; (9) marginalisasi etnik, ras, dan agama (Subono, 2010).

Prostitusi adalah salah satu bentuk pelanggaran Hak Asasi Manusia (HAM) dan bentuk kekerasan terhadap perempuan. la merupakan bagian dari perdagangan manusia dan bentuk eksploitasi seksual dan ekonomi. Dengan dasar argumen bahwa Negara telah melanggar hak warga negaranya, termasuk hak ekonomi dan sosial, yang menjadi penyebab utama jatuhnya perempuan dan anak dalam jurang prostitusi (LBH APIK Semarang, 2010).

Industri prostitusi berada pada sistem ekonomi dan politik yang bekerja dengan memosisikan perempuan sebagai objek pemuas seksual sekaligus komoditas yang menguntungkan. Hal ini merupakan tindakan eksploitasi terhadap citra keperempuanan maupun terhadap tubuh perempuan, karena dalam materi pornografi baik dalam bentuk film atau gambar atau lainnya, utamanya ditujukan untuk melayani kepuasan laki-laki. Penggambaran perempuan yang menjadi objek merupakan pembenaran kekerasan seksual terhadap perempuan (Katjasungkana, 2016).

Karenanya, istilah Prostituted Women atau Perempuan yang Dilacurkan (Pedila) digunakan untuk menyebut perempuan yang dipekerjakan dalam industri prostitusi. Bahwa sejatinya tidak pernah ada perempuan yang sukarela bekerja di industri prostitusi, sistem yang tidak adil dimanfaatkan oleh para pelaku perdagangan dan eksploitasi manusia untuk "menjatuhkan" mereka ke jurang yang penuh eksploitasi dan kekerasan tersebut.

Menurut feminis, prostitusi bukanlah pekerjaan biasa, karena berdasarkan penelitian selama bekerja dengan korban kekerasan terhadap perempuan, khususnya kekerasan seksual, mereka mengakui kesamaan antara pengalaman perempuan yang dilacurkan dengan korban perkosaan, seperti harus memisahkan emosi dari tubuh mereka untuk bertahan hidup, dan menderita gejala shock pasca-trauma dan perasaan negatif tentang tubuh mereka dan diri mereka (Jeffreys, 2009).

Pandangan ini menghadirkan pertentangan antara dorongan untuk mendapatkan uang guna pemenuhan kebutuhan Pedila itu sendiri hingga suatu tindakan eksploitasi yang mengorbankan mereka. Pada akhirnya Pedila bukan lagi pelaku dalam prostitusi, namun justru adalah korban prostitusi. Sebagai korban, prostitusi mengancam Pedila dalam area fisik, sosial, dan psikologis (Lestari, 2016).

Prostitusi mengakibatkan multipel traumatik bagi Pedila, di antaranya 71\% kekerasan fisik, 63\% perkosaan, 89\% tidak menyukai prostitusi tapi tidak berdaya untuk keluar, $75 \%$ tidak memiliki rumah, dan 68\% terkena Post Traumatic Stress Disorder (PSTD) (Nanik, 2012).

Prostitusi merupakan sebuah permasalahan struktural yang mendasar yang terjadi dalam 
masyarakat karena masih dipahami sebagai sebuah permasalahan moral. Persepsi moral ini tanpa disadari akan mengakibatkan sikap menyalahkan Pedila yang ujungnya menjadikan Pedila semakin tertindas (Pisani, 2008).

Selama ini prostitusi di Indonesia dipandang dengan cara pandang patriarki, di mana perempuan sebagai Pedila selalu menjadi obyek dan tudingan sumber permasalahan dalam praktek prostitusi. Pedila dihukum secara moral sebagai pihak pendosa, bahkan dihukum oleh Negara sebagai pelaku tindak pidana. Sedangkan pengguna atau konsumen jasa prostitusi dianggap wajar melakukan pembelian jasa prostitusi.

Itulah mengapa praktik prostitusi akan terus ada selama masih banyak pengguna atau konsumen jasa prostitusi. Seperti halnya teori ekonomi, yaitu Teori Permintaan dan Penawaran, bahwa tanpa adanya permintaan otomatis tidak akan ada penawaran. Menurunkan "permintaan/demand" akan jasa prostitusi dapat dilakukan dengan mengkriminalisasi pengguna atau konsumen jasa prostitusi.

Kriminalisasi adalah salah satu upaya penanggulangan kejahatan melalui kebijakan hukum pidana. Dalam arti luas, kebijakan hukum pidana dapat mencakup ruang lingkup kebijakan di bidang hukum pidana materil, di bidang hukum pidana formal, dan di bidang hukum pelaksanaan pidana. Wisnubroto menyebutkan bahwa kebijakan hukum pidana merupakan tindakan yang berhubungan dalam hal (Arief, 2008): a. Bagaimana upaya pemerintah untuk menanggulangi kejahatan dengan hukum pidana.

b. Bagaimana merumuskan hukum pidana agar sesuai dengan kondisi masyarakat.

c. Bagaimana kebijakan pemerintah untuk mengatur masyarakat dengan hukum pidana.

d. Bagaimana menggunakan hukum pidana untuk mengatur masyarakat dalam rangka mencapai tujuan yang lebih besar.

Gagasan kriminalisasi bagi pengguna atau konsumen jasa prostitusi mendesak untuk dilakukan dalam upaya memutus mata rantai prostitusi. Bila dibandingkan dengan para Pedila yang berada pada situasi tidak punya pilihan, maka para laki-laki konsumen jasa prostitusi mempunyai pilihan untuk memutuskan bahwa dengan membeli jasa Pedila, berarti dikenai sanksi hukum dan sosial yang dapat menghancurkan atau mengancam reputasi dan status sosial mereka sendiri, atau membuat keputusan lain yaitu tidak membeli jasa prostitusi.

Berdasarkan latar belakang masalah yang telah diuraikan, maka tulisan ini akan mencoba menjawab beberapa permasalahan sebagai berikut:

1. Bagaimana pengaturan sanksi pidana bagi pengguna jasa prostitusi di Indonesia?

2. Bagaimana pengaturan sanksi pidana bagi pengguna jasa prostitusi di masa mendatang sebagai upaya untuk memutus mata rantai praktik prostitusi di Indonesia?

\section{B. PEMBAHASAN}

1. Pengaturan Sanksi Pidana bagi Pengguna J asa Prostitusi di Indonesia 
Larangan prostitusi sebenarnya terdapat tidak dapat dikatakan melakukan tindak pidana dalam berbagai peraturan perundang-undangan, sebagaimana diatur dalam Pasal 284 KUHP. hanya saja aturan-aturan tersebut dinilai belum memberikan ketegasan, khususnya bagi pengguna atau konsumen jasa prostitusi. Berbagai peraturan tersebut antara lain:

a. Kitab Undang-Undang Hukum Pidana (KUHP)

KUHP mengatur prostitusi dalam 2 (dua) pasal, yaitu Pasal 296 dan Pasal 506, yang menyatakan:

\section{Pasal 296}

Barangsiapa dengan sengaja menghubungkan atau memudahkan perbuatan cabul oleh orang lain dengan orang lain, dan menjadikannya sebagai pencarian atau kebiasaan, diancam dengan pidana penjara paling lama satu tahun empat bulan atau denda paling banyak seribu rupiah.

\section{Pasal 506}

Barangsiapa menarik keuntungan dari perbuatan cabul seorang wanita dan menjadikan sebagai pencarian, diancam dengan kurungan paling lama satu tahun.

Kedua pasal tersebut hanya dapat menjerat perantara prostitusi, yaitu germo, mucikari, atau pemilik dan/atau pengelola rumah berdir. Tidak ada ketentuan khusus dalam KUHP yang mengatur ancaman pidana bagi pengguna atau konsumen jasa prostitusi, tetapi jika pengguna atau konsumen jasa prostitusi telah beristeri/bersuami maka bisa dikenakan delik zina sebagaimana diatur dalam Pasal 284 KUHP.

Namun delik zina ini adalah delik aduan, sehingga harus ada pengaduan dari pasangan yang sah pelaku zina. Jika tidak ada pengaduan, maka pengguna atau konsumen jasa prostitusi tersebut 
gerak tubuh, atau bentuk pesan lain melalui berbagai bentuk media komunikasi dan/atau pertunjukan di muka umum yang memuat kecabulan atau eksploitasi seksual yang melanggar norma kesusilaan dalam masyarakat.

Tindak pidana pornografi dimuat dalam Pasal 29 sampai dengan Pasal 38 UUP. Apabila dilihat dari sudut perbuatan yang dilarang, maka terdapat 33 tindak pidana pornografi yang dimuat dalam 10 (sepuluh) pasal, antara lain sebagai berikut (Chazawi, 2009):

1) Tindak pidana memproduksi, membuat dan lainnya yang termasuk pornografi (Pasal 29 jo. Pasal 4 ayat 1), terdapat 12 (dua belas) bentuk perbuatan yang dilarang.

2) Tindak pidana menyediakan jasa pornografi (Pasal 30 jo. Pasal 4 Ayat 2)

3) Tindak pidana meminjamkan atau mengunduh produk pornografi (Pasal 31 jo. Pasal 5)

4) Tindak pidana memperdengarkan, mempertontonkan dan lainnya produk pornografi (Pasal 32 jo. Pasal 6), terdapat 6 (enam) perbuatan yang dilarang.

5) Tindak pidana mendanai atau memfasilitasi perbuatan memproduksi, membuat dan lainnya yang termasuk pornografi (Pasal 33 jo. Pasal 7)

6) Tindak pidana sengaja menjadi objek atau model yang mengandung muatan pornografi (Pasal 34 jo. Pasal 8)

7) Tindak pidana menjadikan orang lain sebagai objek atau model yang mengandung muatan pornografi (Pasal 35 jo. Pasal 9)
8) Tindak pidana mempertontonkan diri atau orang lain dalam pertunjukan atau di muka umum (Pasal 36 jo. Pasal 10)

9) Tindak pidana melibatkan anak dalam kegiatan dan/atau sebagai objek dalam tindak pidana pornografi (Pasal 37 jo. Pasal 11)

10) Tindak pidana mengajak, membujuk dan lainnya anak dalam menggunakan produk atau jasa pornografi (Pasal 38 jo. Pasal 12), terdapat 7 (tujuh) perbuatan yang dilarang dalam pasal ini.

Berdasarkan pengertian pornografi dan tindak pidana pornografi tersebut, para pihak dalam industri prostitusi dapat dijerat oleh UU $\mathrm{P}$, antara lain perantara prostitusi yaitu germo dan mucikari, pengguna atau konsumen jasa prostitusi, bahkan Pedila. Namun undang-undang ini hanya membatasi pada pengertian pornografi dalam suatu wujud, misalnya dalam bentuk gambar, sketsa, ilustrasi, foto, tulisan, suara, bunyi, gambar bergerak, animasi, kartun, percakapan, gerak tubuh, atau bentuk pesan lainnya melalui berbagai bentuk media komunikasi dan/atau pertunjukan di muka umum.

d. Undang-Undang Nomor 35 Tahun 2014 tentang Perubahan Atas Undang-Undang Nomor 23 Tahun 2002 tentang Perlindungan Anak (UU PA)

Prostitusi yang melibatkan anak sebagai Pedila dikenal dengan istilah Eksploitasi Seks Komersial Anak (ESKA). Agenda Aksi Stokholm mendefinisikan ESKA sebagai (Mahartika, 2018):

"Sebuah pelanggaran mendasar terhadap hak-hak anak. Pelanggaran tersebut terdiri dari kekerasan seksual oleh orang dewasa dan pemberian imbalan dalam bentuk uang tunai 
atau barang terhadap anak, atau orang ketiga, atau orang-orang lainnya. Anak tersebut diperlakukan sebagai sebuah objek seksual dan sebagai objek komersial. Eksploitasi seksual komersial anak merupakan sebuah bentuk pemaksaan dan kekerasan terhadap anak dan mengarah pada bentuk kerja paksa serta perbudakan modern."

Di Indonesia, Pasal 76I UU PA melarang eksploitasi anak dengan menegaskan bahwa "Setiap orang dilarang menempatkan, membiarkan, melakukan, menyuruh melakukan, atau turut serta melakukan eksploitasi secara ekonomi dan/atau seksual terhadap anak".

Dalam penjelasan dijelaskan bahwa yang dimaksud dengan "dieksploitasi secara ekonomi" adalah tindakan dengan atau tanpa persetujuan anak yang menjadi korban yang meliputi tetapi tidak terbatas pada pelacuran, kerja atau pelayanan paksa, perbudakan atau praktik serupa perbudakan, penindasan, pemerasan, pemanfaatan fisik, seksual, organ reproduksi, atau secara melawan hukum memindahkan atau mentransplantasi organ dan/atau jaringan tubuh atau memanfaatkan tenaga atau kemampuan anak oleh pihak lain untuk mendapatkan keuntungan materil. Sedangkan yang dimaksud dengan "dieksploitasi secara seksual" adalah segala bentuk pemanfaatan organ tubuh seksual atau organ tubuh lain dari anak untuk mendapatkan keuntungan, termasuk tetapi tidak terbatas pada semua kegiatan pelacuran dan pencabulan.

Ketentuan tersebut di atas menunjukkan bahwa membeli jasa prostitusi merupakan sebuah delik atau perbuatan yang melawan hukum. Artinya, pengguna atau konsumen jasa prostitusi dapat dikenai sanksi pidana. Namun demikian pengguna atau konsumen jasa prostitusi tersebut hanya dapat dikenai sanksi pidana jika Pedila masih berusia anak.

e. Undang-Undang Nomor 19 Tahun 2016 tentang Perubahan Atas Undang-Undang Nomor 11 Tahun 2008 tentang Informasi dan Transaksi Elektronik (UU ITE)

UU ITE tidak menyebut kata prostitusi dalam semua pasalnya, kecuali norma dalam Pasal 27 yang berisikan perbuatan yang dilarang yaitu mendistribusikan dan/atau mentransmisikan dan/atau membuat dapat diaksesnya informasi elektronik dan/atau dokumen elektronik yang memiliki muatan yang melanggar kesusilaan.

Lebih lanjut, dalam Ketentuan Umum dijelaskan bahwa Informasi elektronik adalah satu atau sekumpulan data elektronik, termasuk tetapi tidak terbatas pada tulisan, suara, gambar, peta, rancangan, foto, electronic data interchange (ED4, surat elektronik, telegram, teleks, telecopy, atau sejenisnya, huruf, tanda, angka, kode akses, simbol, atau perforasi yang telah diolah yang memiliki arti atau dapat dipahami oleh orang yang mampu memahaminya. Sedangkan yang dimaksud dengan Dokumen Elektronik adalah setiap informasi elektronik yang dibuat, diteruskan, dikirimkan, diterima, atau disimpan dalam bentuk analog, digital, elektromagnetik, optikal, atau sejenisnya, yang dapat dilihat, ditampilkan, dan/atau didengar melalui Komputer atau Sistem Elektronik, termasuk tetapi tidak terbatas pada tulisan, suara, gambar, peta, rancangan, foto, atau sejenisnya, huruf, tanda, angka, 
kode akses, simbol atau perforasi yang memiliki makna atau arti atau dapat dipahami oleh orang yang mampu memahaminya.

Pasal 27 UU ITE dapat digunakan untuk menjerat siapa saja, termasuk pengguna atau konsumen jasa prostitusi, yang berhubungan dengan kejahatan "mendistribusikan atau membuat diaksesnya informasi elektronik yang melanggar kesusilaan. Namun objek perbuatan kesusilaan ini harus disebarluaskan ke publik melalui media elektronik, misalnya media sosial, email, atau layanan pesan singkat. Pasal ini tidak berhubungan dengan perbuatan membeli jasa prostitusi.

\section{Pengaturan Sanksi Pidana bagi Pengguna} Jasa Prostitusi di Masa Mendatang Sebagai Upaya untuk Memutus Mata Rantai Praktik Prostitusi di Indonesia

Upaya penanggulangan kejahatan dengan menggunakan hukum pidana merupakan bagian dari kebijakan kriminal (criminal policy). Menurut Marc Ancel, kebijakan kriminal adalah suatu usaha yang rasional dari masyarakat dalam menanggulangi kejahatan. Pengertian kebijakan kriminal juga dikemukakan oleh G. Peter Hoefnagels yaitu bahwa "Criminal policy is the rational organization of the social reaction to crime". Definisi lainnya yang dikemukakan oleh G. Peter Hoefnagels adalah (Arief, 2008):

a. Criminal policy is the science of responses;

b. Criminal policy is the science of crime prevention;

c. Criminal policy is a policy of designating human behaviour as crime; d. Criminal policy is a rational total of the response of crime.

Kebijakan kriminal (criminal policy) dapat dilakukan melalui sarana penal (penal policy) dan non penal (non penal policy). Sarana penal adalah upaya penanggulangan kejahatan yang sifatnya represif, yaitu menggunakan hukum pidana. Sedangkan sarana non penal adalah upaya penanggulangan kejahatan yang sifatnya preventif dengan menggunakan sarana di luar hukum pidana.

Marc Ancel secara singkat memberikan definisi bahwa sarana penal sebagai suatu ilmu sekaligus seni yang mempunyai tujuan praktis untuk memungkinkan peraturan hukum positif dirumuskan secara lebih baik. Dapat disimpulkan bahwa menurut Marc Ancel istilah sarana penal sama dengan istilah kebijakan hukum pidana (Arief, 2008).

Dalam arti luas, kebijakan hukum pidana dapat mencakup ruang lingkup kebijakan di bidang hukum pidana materil, di bidang hukum pidana formal, dan di bidang hukum pelaksanaan pidana. Wisnubroto menyebutkan bahwa kebijakan hukum pidana merupakan tindakan yang berhubungan dalam hal (Arief, 2008):

e. Bagaimana upaya pemerintah untuk menanggulangi kejahatan dengan hukum pidana.

f. Bagaimana merumuskan hukum pidana agar sesuai dengan kondisi masyarakat.

g. Bagaimana kebijakan pemerintah untuk mengatur masyarakat dengan hukum pidana.

h. Bagaimana menggunakan hukum pidana untuk mengatur masyarakat dalam rangka mencapai tujuan yang lebih besar. 
Salah satu upaya penanggulangan kejahatan melalui sarana penal atau kebijakan hukum pidana dapat dilakukan dengan mengkriminalisasikan suatu perbuatan. Kriminalisasi (criminalization) merupakan objek studi hukum pidana materiil (subtantive criminal law) yang membahas penentuan suatu perbuatan sebagai tindak pidana (perbuatan pidana atau kejahatan) yang diancam dengan sanksi pidana tertentu. Perbuatan tercela yang sebelumnya tidak dikualifikasikan sebagai perbuatan terlarang dijustifikasi sebagai tindak pidana yang diancam dengan sanksi pidana (Mulyadi, 2017).

Menurut Soetandyo Wignjosoebroto, kriminalisasi adalah suatu pernyataan bahwa perbuatan tertentu harus dinilai sebagai perbuatan pidana yang merupakan hasil dari suatu penimbangan-penimbangan normatif (judgments) yang wujud akhirnya adalah suatu keputusan (decisions) (Wignjosoebroto, 1993).

Kriminalisasi dapat pula diartikan sebagai proses penetapan suatu perbuatan seseorang sebagai perbuatan yang dapat dipidana. Proses ini diakhiri dengan terbentuknya undang-undang di mana perbuatan itu diancam dengan suatu sanksi yang berupa pidana (Sudarto, 1986).

Sebagai bahan perbandingan, Indonesia bisa belajar dari negara-negara Skandinavia yang berhasil mengatasi prostitusi secara efektif, salah satunya Swedia. Melalui Undang-Undang Prostitusi Swedia (Sex Puschase Act/Sexkopslagen) yang diperkenalkan sejak 1 Januari 1999, Pemerintah Swedia memulai penutupan lokalisasi dengan mengkriminalisasi atau memberikan sanksi hukuman bagi pengguna atau konsumen jasa prostitusi. Sedangkan Pedila diposisikan sebagai korban yang harus diupayakan untuk keluar dari dunia prostitusi melalui berbagai program pemulihan dan pemberdayaan (Sonbai, 2019).

Untuk itu selama satu dekade atau 10 (sepuluh) tahun, Pemerintah Swedia melancarkan program pendidikan untuk para laki-laki, paralel dengan program dukungan dan pelayanan untuk para Pedila sebagai korban, serta mengenakan sanksi tegas terhadap pengguna atau konsumen jasa prostitusi dan pelaku kekerasan dengan melakukan penangkapan besar-besaran (Katjasungkana, 2014).

Laporan resmi pemerintah Swedia dalam Skarhed Report yang dirilis pada tahun 2010 menyebutkan, undang-undang tersebut telah mengurangi aktivitas prostitusi serta menurunkan jumlah pengguna atau konsumen jasa prostitusi sampai lebih dari 40 persen (Tirto.id, 2017). Jumlah Pedila juga turun secara drastis lebih dari 30 persen (Prior, 2014).

Keberhasilan pemerintah Swedia membuat negara tetangganya seperti Islandia dan Norwegia mencontoh aturan tersebut pada tahun 2009. Parlemen Eropa juga memutuskan untuk melakukan hal serupa dengan menghukum para pengguna atau konsumen jasa prostitusi (Tirto.id, 2017).

Sejalan dengan Pemerintah Swedia, Pemerintah Jepang juga mengupayakan pemberantasan perdagangan manusia, termasuk prostitusi, dengan menerapkan kebijakan yang ditujukan untuk mengurangi "permintaan/demand" dengan cara membongkar yakuza, meningkatkan 
dukungan untuk identifikasi Pedila, dan Legislasi Nasional (Prolegnas) Prioritas Dewan mengembangkan kemitraan regional melawan Perwakilan Rakyat (DPR) sejak 2016, namun hingga perdagangan manusia (Jones, 2010).

Terbukti bahwa menurukan "permintaan / kini belum juga disahkan. Pasal 3 RUU PKS demand" akan jasa prostitusi dengan menuntut pertanggungjawaban pidana pengguna atau konsumen jasa prostitusi merupakan solusi yang efektif. Belajar dari Pemerintah Swedia yang mengembangkan respon peraturan berseberangan dengan ideologi patriarki yang dominan, maka aturan serupa dapat dilakukan Pemerintah Indonesia dengan beberapa pilihan.

Pertama, Indonesia harus memiliki aturan atau undang-undang yang mengatur mengenai prostitusi. Tidak hanya menjerat perantara prostitusi, yaitu yaitu germo, mucikari, atau pemilik dan/atau pengelola rumah berdir, tapi juga pengguna atau konsumen jasa prostitusi. Sedangkan Pedila diupayakan untuk keluar dari dunia prostitusi melalui berbagai program pemulihan dan pemberdayaan yang merupakan bentuk dari rehabilitasi sosial.

Menurut Supiadi, rehabilitasi sosial adalah segenap upaya yang ditujukan untuk mengintegrasikan seseorang kembali ke dalam kehidupan masyarakat dengan cara membantunya menyesuaikan diri dengan tuntutan keluarga, komunitas, dan pekerjaan sejalan dengan pengurangan setiap beban sosial dan ekonomi yang dapat merintangi proses rehabilitasi (Ramadhani, 2017).

Kedua, melalui pengesahan Rancangan Undang-Undang (RUU) Penghapusan Kekerasan Seksual (PKS). RUU PKS terdaftar dalam Program menegaskan bahwa Penghapusan Kekerasan Seksual antara lain bertujuan untuk: (1) mencegah segala bentuk kekerasan seksual; (2) menangani, melindungi dan memulihkan korban; (3) menindak pelaku; dan (4) menjamin terlaksananya kewajiban negara dan peran dan tanggung jawab keluarga, masyarakat dan korporasi dalam mewujudkan lingkungan bebas kekerasan seksual. Ketentuan Pasal 13 dalam RUU PKS dapat digunakan dalam menindak pengguna atau konsumen jasa prostitusi, yang menyatakan bahwa:

\section{Pasal 13}

Setiap orang dengan kekerasan, ancaman kekerasan, tipu daya, rangkaian kebohongan, nama atau identitas atau martabat palsu, atau penyalahgunaan kepercayaan, agar seseorang melakukan hubungan seksual dengan orang lain, atau perbuatan yang memanfaatkan tubuh orang tersebut yang terkait hasrat seksual, dengan maksud menguntungkan diri sendiri atau orang lain, diancam pidana eksploitasi seksual.

\section{SIMPULAN}

Pemerintah Indonesia memiliki berbagai peraturan perundang-undangan terkait larangan prostitusi, antara lain (1) Kitab Undang-Undang Hukum Pidana; (2) Undang-Undang Nomor 21 Tahun 2007 tentang Tindak Pidana Perdagangan Orang; (3) Undang-Undang Nomor 44 Tahun 2008 tentang 
Pornografi; (4) Undang-Undang Nomor 35 Tahun 2014 tentang Perubahan Atas Undang-Undang Nomor 23 Tahun 2002 tentang Perlindungan Anak; dan (5) Undang-Undang Nomor 19 Tahun 2016 tentang Perubahan Atas Undang-Undang Nomor 11 Tahun 2008 tentang Informasi dan Transaksi Elektronik. Namun aturan-aturan tersebut dinilai belum memberikan ketegasan, khususnya bagi pengguna atau konsumen jasa prostitusi.

Belajar dari Pemerintah Swedia yang berhasil mengatasi prostitusi mengembangkan respon peraturan berseberangan dengan ideologi patriarki yang dominan, maka menurunkan "permintaan/demand" akan jasa prostitusi dengan menuntut pertanggungjawaban pidana pengguna atau konsumen jasa prostitusi juga dapat dilakukan Pemerintah Indonesia dengan beberapa pilihan, antara lain:

1. Membuat aturan atau undang-undang yang mengatur mengenai prostitusi. Tidak hanya menjerat perantara prostitusi, yaitu germo, mucikari, atau pemilik dan/atau pengelola rumah berdir, tapi juga pengguna atau konsumen jasa prostitusi. Sedangkan Pedila diupayakan untuk keluar dari dunia prostitusi melalui berbagai program pemulihan dan pemberdayaan.

2. Mengesahkan Rancangan Undang-Undang (RUU) Penghapusan Kekerasan Seksual (PKS) yang telah terdaftar dalam Program Legislasi Nasional (Prolegnas) Prioritas Dewan Perwakilan Rakyat (DPR) sejak 2016. Ketentuan Pasal 13 dalam RUU PKS dapat digunakan dalam menindak pengguna atau konsumen jasa prostitusi.

\section{DAFTAR PUSTAKA}

\section{BUKU}

Arief, Barda N. (2008). Bunga Rampai Kebijakan Hukum Pidana. Jakarta: Kencana.

Chazawi, A. (2009). Tindak Pidana Pornografi. Surabaya: Putra Media Nusantara.

LBH APIK Semarang. (2010). Situasi Trafficking terhadap Perempuan di Semarang. Semarang: LBH APIK Semarang.

Mulyadi, Lilik. (2017). Kapita Selekta Hukum Pidana Kriminologi dan Viktimologi. Jakarta: Djambatan.

Pisani, E. (2008). Kearifan Pelacur: Kisah Gelap di Balik Bisnis Seks dan Narkoba. Jakarta: Serambi.

Sudarto. (1986). Kapita Selekta Hukum Pidana. Bandung: Alumni.

Jeffreys, S. (2009). The Industrial Vagina: The Political Economy and The Global Sex Trade. New York: Routledge.

\section{JURNAL}

Lestari, Made Diah., Sulistiowati, Ni Made Dian., \& Natalya, Ni Putu. (2016). Kesehatan Seksual dan Reproduksi Serta Fasilitas Kesehatan di Lokasi Prostitusi: Community Based Participatory Research dengan Photovoice pada Pekerja Seksual di Gunung Lawu Bali. J urnal Psikologi Universitas Diponegoro Vol.15, (No.1), p. 78.

Nanik, S. (2012). Fenomena Keberadaan Prostitusi dalam Pandangan Feminisme. J urnal Wacana, Vol.15, (No.4), p. 25. 
Jurnal Pembangunan Hukum Indonesia

Volume 1, Nomor 3, Tahun 2019
Program Studi Magister IImu Hukum Fakultas Hukum Universitas Diponegoro
Jones, A. (2010). Human Trafficking, The Japanese

Commercial Sex Industry and The Yakuza: Recommendations for the Japanese Goverment.. Student Pulse J ournal Quest Vol. 3, (No. 2), p. 1.

Katjasungkana, Soka H. (2016). Narasi Perempuan dan Kekerasan Seksual dalam Hukum Indonesia. J urnal Perempuan, Edisi 89, Vol.21, (No. 2, Mei 2016), p. 131.

Nazemi, N. (2011). Legalizing Prostitution Means Legitimizing Human Rights Violation. International J ournal of Humanities and Social Science, Vol. 1, (No.9), p. 114.

Prior, J. (2014). Kehadiran, Kesabaran, Ketekunan: Misi dalam sebuah Pusat Perdagangan Manusia. J urnal Ledalero, Vol.13, (No.1), p. 13. Ramadhani, Widya Suci,. Sulastri, Sri., \& Nurhaqim, Ahmad Soni. (2017). Proses Rehabilitasi Sosial Wanita Tuna Susila di Balai Rehabilitasi Sosial Karya Wanita Palimanan Kabupatan Cirebon. Jurnal Penelitian dan PKM, VoL.4, (No.2), p. 244.

Sonbai, Alexander Imanuel K. (2019). Kebijakan Formulasi Pertanggungjawaban Pidana Pengguna Jasa Prostitusi Melalui Media Online. J urnal Hukum Kenotariatan Acta Comitas, Vol.4, (No.2), p. 281.

Subono, Nur I. (2010). Trafficking in Human Beings dalam Angka dan Perdebatan. Jurnal Perempuan Edisi 68 Tahun 2010, p. 21.

Khumaerah, N. (2017). Patologi Sosial Pekerja Seks Komersial Perspektif Al-Quran. Jurnal Al-Khitabah, Vol. III, (No 1-Juni), pp. 63-64.

\section{PROCEEDING CONFERENCE}

Wignjosoebroto, S. (1993). Kriminalisasi dan Dekriminalisasi: Apa yang Dibicarakan Sosiologi Hukum tentang Hal Ini, disampaikan dalam Seminar Kriminalisasi dan Dekriminalisasi dalam Pembaharuan Hukum Pidana di Indonesia, Fakultas Hukum UII, Yogyakarta 15 Juli 1993.

\section{TESIS \& ARTIKEL}

Mahartika, L. (2018). Pengaruh End Child Postitution, Child Pornography, and Trafficking of Children for Sexual Pusposes dalam Kasus Eksploitasi Pariwisata Seks Anak di Thailand. Universitas Muhammadiyah Yogyakarta.

Tampi, B. (2010). Kejahatan Kesusilaan dan Pelecehan Seksual dalam Hukum Pidana Indonesia. Karya Ilmiah Fakultas Hukum, Universitas Sam Ratulangi, Manado.

\section{PERATURAN PERUNDANG-UNDANGAN}

Kitab Undang-Undang Hukum Pidana

Undang-Undang Nomor 21 Tahun 2007 tentang

Tindak Pidana Perdagangan Orang

Undang-Undang Nomor 44 Tahun 2008 tentang Pornografi

Undang-Undang Nomor 35 Tahun 2014 tentang

Perubahan Atas Undang-Undang Nomor 23

Tahun 2002 tentang Perlindungan Anak; Undang-Undang Nomor 19 Tahun 2016 tentang Perubahan Atas Undang-Undang Nomor 11 Tahun 2008 tentang Informasi dan Transaksi Elektronik. 
Jurnal Pembangunan Hukum Indonesia

Volume 1, Nomor 3, Tahun 2019

\section{SUMBER ONLINE}

Katjasungkana, Soka H. (2014). Penutupan

Lokalisasi Dolly dan Industri Seks. Diakses

melalui

https://www.jurnalperempuan.org/blog/penutup

an-lokalisasi-dolly-dan-industri-seks, pada 29

tanggal Agustus 2019.

Tirto.id. (2017). Bagaimana Negara Lain Menyikapi

Prostitusi?. Diakses melalui

https://tirto.id/bagaimana-negara-lain-menyika

pi-prostitusi-czkc, pada tanggal 4 September

2019
Program Studi Magister IImu Hukum Fakultas Hukum Universitas Diponegoro 